\title{
The effect of milk yield on some reproductive parameters of the Elsenburg Holstein and Jersey herds
}

\author{
C.J.C. Muller" ${ }^{\#}$ F.J. du Toit, C. Singhapol and J.A. Botha \\ Chief Directorate: Agriculture: Private Bag X1, Elsenburg, 7607 \\ \#e-mail:carelm@wcape.agric.za
}

\section{Introduction}

Profitable milk production and genetic improvement of dairy herds depend largely on the reproduction efficiency maintained in herds. Various factors influence the reproductive performance of dairy cows. Some of these factors include accurate heat detection methods, insemination techniques such as storage, thawing and handling of semen. Herd size and possible mineral imbalances may also affect the reproductive performance in dairy herds. Recently the effect of milk yield on reproduction has also received some attention as the average yields of dairy cows have increased over time. The general feeling is that cows with higher milk yields will have lower fertilities. Butler \& Smith (1989) confirmed this in a study where higher milk yields resulted in reduced conception rates i.e. $66 \%$ in 1951 vs. $40-50 \%$ in 1975 . National milk recording data in Britain has also shown that higher yielding herds have longer calving intervals varying from 378 days for herds producing $6000 \mathrm{~kg}$ milk to 393 days for herds varying in milk yield between 8500 to $9500 \mathrm{~kg}$ (NMR, 1999) This variation could, however, also be because of factors such as differences between farms, management level and personal involvement of managers. As the average milk yield of the Elsenburg Holstein and Jersey herds increased substantially over the last 15 years (Muller et al., 1994; Muller et al., 1995) while managed under the same conditions, the effect of increasing milk yield levels on some reproductive parameters in the two herds was determined.

\section{Materials and Methods}

Reproductive parameters such as number of days to first heat, number of days to conception and number of insemination per conception (including services by bulls) were collected for all Holstein $(n=543)$ and Jersey $(n=$ 331) primi- and multiparous cows that completed a standard lactation for milk recording purposes during the period from 1980 to 1998. Simple linear regressions of these reproductive parameters on production parameters (milk, fat and protein yields) were fitted within lactation number for cows in both Holstein and Jersey herds.

\section{Results and Discussion}

Days to first heat for both primiparous Holstein and Jersey cows increased $(\mathrm{P}<0.05)$ with higher milk yields (Table 1). Other parameters such as number of days to conception and number of inseminations per conception increased $(\mathrm{P}<0.05)$ only for primiparous Holstein cows. Reproductive parameters for other lactation groups for both Holstein and Jersey cows were not affected $(\mathrm{P}>0.05)$ by increasing milk yield levels.

Table 1 The effect of increasing milk yield (per $1000 \mathrm{~kg}$ ) on some reproductive parameters of the Elsenburg Holstein and Jersey herds.

\begin{tabular}{lcllll}
\hline Parameters & $\begin{array}{c}\text { Lactation } \\
\text { number }\end{array}$ & $\begin{array}{l}\text { Holstein } \\
\mathrm{x} \text {-coeff }\end{array}$ & $\mathrm{R}^{2}$ & $\begin{array}{l}\text { Jersey } \\
\text { x-coeff }\end{array}$ & $\mathrm{R}^{2}$ \\
\hline Days of first heat & 1 & 3.6 & $0.0235^{*}$ & 3.4 & $0.0440^{*}$ \\
& 2 & 1.1 & 0.0026 & -8.6 & 0.0433 \\
& 3 & 1.4 & 0.0027 & -6.7 & 0.0187 \\
Days of conception & 4 & 7.1 & 0.0018 & 0.44 & 0.0133 \\
& 1 & 11.1 & $0.0449^{*}$ & 3.2 & 0.0012 \\
& 2 & -7.9 & 0.0115 & -11.9 & 0.0045 \\
Number of inseminations per & 3 & 7.9 & 0.0185 & -7.8 & 0.0034 \\
conception & 4 & 10.7 & 0.0131 & 16.5 & 0.0205 \\
& 1 & 0.210 & $0.0556^{*}$ & 0.19 & 0.0238 \\
& 2 & 0.011 & 0.0002 & 0.03 & 0.0002 \\
*P $<0.05$ & 3 & 0.098 & 0.0127 & 0.07 & 0.0015 \\
& 4 & 0.128 & 0.0153 & 0.35 & 0.0398 \\
\hline
\end{tabular}

*P $<0.05$ 


\section{Short paper and poster abstracts: $38^{\text {th }}$ Congress of the South African Society of Animal Science}

Although an increase in milk yield of $1000 \mathrm{~kg}$ per lactation was associated with poorer reproductive performances, this relationship was relatively low as depicted by $\mathrm{R}^{2}$-values of only $0.0235,0.0449$ and 0.0556 for Holstein primiparous Holstein cows. These values indicate that a large percentage of variation in reproductive performance of dairy cows is due to other factors. A study by Farin et al. (1994) using 1.2 million Holstein and 50 000 Jersey cows in the USA indicated that as the milk yield in dairy herds increased with increasing herd size, days to first heat and days to conception (days open) decreased in both Holstein and Jersey herds. Number of services per conception increased only in Holstein herds. This information was gathered from 9684 Holstein and 546 Jersey herds and illustrates the effects that managers, inseminators and other factors have on reproductive performance as well as milk yield. From these results a threshold yield beyond which pregnancy rates appeared to be depressed was $8025 \mathrm{~kg}$ of mature equivalent fat corrected milk (FCM). Another study by Faust et al. (1988) found that reproductive performance of primiparous Holstein cows in North Carolina decreased when FCM yield was higher than $7250 \mathrm{~kg}$. No clear threshold milk yield was found in the present study. More than $62 \%$ of all primiparous Holstein cows were pregnant by 76 days after calving. Some researchers have reported a negative relationship between high milk yields and fertility (Imakawa et al., 1987) and others have not (McClure, 1970). Numerous factors can confound the relationship between milk production and fertility. Calving interval measures are subject to management policy and are influenced by heat detection, voluntary waiting period and conception rate (Samuels, 1990).

\section{Conclusions}

Higher milk yields resulted in poorer reproduction performances only in primiparous cows in the Elsenburg Holstein and Jersey herds. Low $\mathrm{R}^{2}$ values indicated that other factors also contribute largely to poor reproductive performances.

\section{References}

Butler, W.R. \& Smith, R.D., 1989. Interrelationships between energy balance and post partum reproductive function in dairy cattle. J. Dairy Sci. 72, 767.

Farin, P.W., Slenning, B.D., Correa, M.T. \& Britt, J.H., 1994. Effects of calving season and milk yield on pregnancy risk and income on North Carolina Holstein cows. J. Dairy Sci. 77, 1848.

Faust, M.A., McDaniel, B.T., Robison, O.W. \& Britt, J.H., 1988. Environmental and yield effects on reproduction in primiparous Holsteins. J. Dairy Sci. 71, 3092.

Imakawa, K. Day, M.L., Zolesky, D.D., Clutter, A., Kittok, R.J. \& Kinder, J.E., 1987. Effects of 17ß-estradiol and diets varying in energy on secretion of luteïnizing hormone in beef heifers. J. Anim. Sci. 68, 805.

McClure, T.J., 1970. An experimental study of the causes of a nutritional and lactational stress infertility of pasture-fed cows, associated with loss of body weight at about time of mating. Res. Vet. Sci. 11, 247.

Muller, C.J.C., Shipman, A. \& Cloete, S.W.P., 1994. Phenotypic and genetic trends in the milk production of the Elsenburg Friesland herd. SASAS Congress 28-31 March 1994. Warmbad. p. 53.

Muller, C.J.C., Shipman, A.H.C. \& Botha, J.A., 1995. Phenotypic and genetic trends in the milk production of the Elsenburg Jersey herd. SASAS Congress. 11-13 April 1995. Bloemfontein. p. 17.

National Milk Recording, 1999. Higher yields, lower fertility. Dairy Farmer 46 (5), 24.

Samuels, W.A., 1990. Genetic gains limit milk production of dairy cows. Feedstuffs. 62 (7), 13. 